\title{
OS FRAGMENTOS DO ENSAIO DE JOAQUiM NABUCO
}

\author{
Ricardo Souza de Carvalho
}

\section{O LABORATÓRIO TEXTUAL}

Na primeira entrada do diário de Joaquim Nabuco (2006, p. 24), de 31 de agosto de 1873, quando viajava pela primeira vez à Europa, aos 24 anos, apenas constava: "Partida para Bordéus no Chimborazo. Comandante Massey (George)". Na última, de 11 de janeiro de 1910, sete dias antes de falecer, registrou: "Um pouco melhor. Não tive vertigem à noite. Retomo com prudência minha vida usual. Tenho sempre a dor de cabeça e sonolência" (p. 721). O intervalo de 36 anos de diário é demarcado pelo encontro a bordo com Eufrásia Teixeira Leite, que se tornaria uma grande paixão, aliado à perspectiva de todo um novo mundo de artes e tradições no Velho Mundo; e pelos recorrentes problemas de saúde que comprometiam o curso normal do cotidiano. Ou ainda, pela antevéspera descompromissada e promissora da vida adulta e pela antevéspera ignorada da morte. Durante esse tempo, Nabuco lançou-se para fora das páginas do diário em centenas de cartas, dezenas de artigos para jornal, panfletos e discursos políticos e livros de diversos gêneros, de uma coletânea de poemas (1874) até um livro de "pensamentos soltos e lembranças" (1906), ambos em francês. O que parece à primeira vista uma grande variedade de práticas discursivas poderia ser englobado em duas grandes modalidades: as escritas de si e a prosa ensaística. Entre os dois grupos, estabeleceram-se relações de continuidade e de familiaridade em sintonia com os dilemas de um Nabuco que queria ser reconhecido como homem de letras, mas que não revelava maiores aptidões para os gêneros 
consagrados da ficção, optando por experimentar fragmentos de escrita híbridos em suas formas e múltiplos em seus propósitos.

Por meio das escritas de si, Nabuco ofereceu, em alguns momentos estratégicos de sua trajetória, representações do escritor que tinha que se posicionar entre diferentes tipos de produção textual. Em carta de $1^{\circ}$ de fevereiro de 1865 a um jovem escritor em ascensão, Machado de Assis, um Nabuco de apenas 15 anos oferecia uma personalidade literária que negava a vocação para a poesia e se encaminhava ao "positivo", cuja argumentação pretensiosa era concluída por uma previsão:

“[...] mas um dia virá, e este dia talvez esteja perto, no qual me desligue completamente desse mundo de visionários, para ir tomar parte no grêmio daqueles que, mais chegados às realidades da vida, consideram este mundo como ele realmente é" (NABUCO apud ARANHA, 2003, p. 90).

Em lugar de uma postura tomar o lugar da outra, Nabuco manteve por anos a convivência instável entre os extremos do "mundo de visionários" na poesia esparsa e das "realidades da vida" nos frequentes escritos vinculados à esfera pública, enquanto se projetava nas escritas de si, que funcionavam como uma espécie de ponto de equilíbrio entre diversas tendências.

Já em sua autobiografia, Minha formação (1900), Nabuco construiu um autorretrato do escritor que justificaria uma trajetória errática ou mesmo fracassada nas letras. O capítulo VIII, "A crise poética”, não desmentia o diagnóstico impiedoso do adolescente da carta a Machado diante da evidente falta de valor do livro de poesia Amour et Dieu, resignado por não ter lhe cabido "em partilha nem o verso, nem a arte" (NABUCO, 2012, p. 96). Por outro lado, passava a valorizar o conselho do seu ídolo Ernest Renan, justamente à época desse arroubo poético, de seguir os estudos históricos como uma "profissão literária séria", e do qual resultou Um estadista do Império, solução apropriada para a "crise poética” - e, por extensão, literária - que se arrastava por um longo tempo. Sob a encenação de uma carreira literária chegada a bom termo, as escritas de si subjazem à realização não apenas dessa grande obra, mas de toda uma prática ensaística, permitindo reavaliar o lugar marginal ou subsidiário a que se possa relegar essa parcela da produção de Nabuco, assim como propõe Brigitte Diaz (2016, p. 244) em relação à carta e seus congêneres:

[...] Diremos antes que as maiores obras do escritor são as partes emersas do iceberg, talvez as mais belas - é uma questão de gosto -, mas que elas se apoiam em outras menos visíveis - cartas, cadernetas, diários, às quais estão amarradas por ligações tentaculares. Assim a tentação é grande, e provavelmente legítima, 
de estudar essas correspondências como as peças espalhadas de um imenso dossiê genético; não porque seriam os documentos preparatórios de cada texto considerado em particular, mas porque constituem um tipo de laboratório da obra toda, incluindo nesse termo a obra que o escritor faz de sua própria vida. Muito mais do que hipotéticos prototextos, as cartas participam a seu modo da invenção de um estilo.

Especialmente os diários e as cartas de Nabuco encontravam-se entrelaçados por "ligações tentaculares", passando a assumir esse papel de "laboratório da obra toda". As afinidades entre as duas escritas seriam inevitáveis, uma vez que o diário teria surgido durante a segunda metade do século XVIII "da interiorização da carta entre amigos", da "ideia incrível de pegar um papel para não escrever a ninguém, para escrever a si mesmo, para se escrever" (LEJEUNE, 2014, p. 362). A partir de então, não poucos autores escreviam, sob o registro de uma data, ora para alguém, ora para si mesmos. Dessa maneira, além do compartilhamento de assuntos e de procedimentos, uma escrita poderia se remeter para a outra, quando Nabuco comentava no diário as cartas enviadas ou recebidas, e até mesmo fazia o rascunho de muitas delas.

Levando em conta a noção de um laboratório textual, no qual se experimentaria uma ampla variedade de estilos e de gêneros, estudiosos costumam associar a carta e o diário a outra forma híbrida por excelência, o ensaio. Brigitte Diaz (2016, p. 100) defende que "a modalidade discursiva e dialógica da carta a predispõe a se tornar o suporte de ensaios literários e críticos", lembrando que são muitas "cartas privadas que se desprendem de suas amarras de origem para se tornarem prefácio, panfleto ou ainda manifesto", e que, no sentido inverso, "o artigo crítico ou o ensaio literário assumem facilmente, no século XIX, a forma epistolar, julgada menos pesada que o habitual relatório crítico". Nabuco escreveu, entre outros, um ensaio sobre o meio desfavorável à arte no Brasil, em carta de 10 de novembro de 1882 , ao pintor Pedro Américo, que lhe havia remetido o romance que escrevera, $O$ holocausto (1882), para a sua apreciação (NABUCO, 1949a, pp. 78-82).

Quanto ao diário, segundo Philippe Lejeune (2014, p. 305), “desloca a atenção para um processo de criação, torna o pensamento livre, mais aberto a suas contradições, e comunica ao leitor a dinâmica da reflexão tanto quanto seu resultado", o que nos permite remetê-lo à melhor tradição do ensaio. Uma amostra desse processo encontra-se na entrada de 14 de agosto de 1877 do diário de Nabuco, na qual, na continuação do 
deslumbramento da visita às cataratas do Niágara, volta-se ao aniversário do pai, o senador Nabuco de Araújo, que faleceria no ano seguinte:

Dia dos anos de meu Pai. Sessenta e quatro anos hoje. É este um dia grande para muitos, e Deus lhe dê uma vida longa para glória de seu país e felicidade de seus filhos.

O ruído externo da cachoeira faz-me sentir que há uma vida mais vasta e maior em torno de mim: a da Natureza. Aqui nunca se está só. Esse constante cair de um rio no abismo sugere pensamentos grandes demais para a simples melancolia pessoal. Se René veio aqui, voltou curado. O destino de um homem desaparece no do Todo como uma rocha nas espumas da queda. O trabalho ativo e vivificante do mundo está diante de mim em uma de suas magníficas manifestações. Todavia não é de Deus que se pensa diante do Niágara. Quando se vai a Goat Island vê-se a história do rio escrita nas pedras do leito. A geologia aqui vence a fé. $\mathrm{O}$ que se vê é a obra que esse rio realizou, e as mudanças na conformação da horseshoe são contemporâneas. A catarata recua, a rocha cede sob a massa de água e em milhares de anos será perto do lago Erie que o homem terá a grande vista das cachoeiras do Niágara. Nobre rio, cuja história é a de muito grande homem, ou pelo menos que é a imagem viva de uma grande vida (NABUCO, 2006, pp. 188-189).

O mero registro de eventos díspares sob uma mesma data torna-se uma prosa de impressões que, ao descartar visadas pessoais e metafísicas, dá lugar a uma correlação, usual no século XIX, entre geologia e história, ou melhor, entre uma história de longa duração, visível nas rochas configuradas por um "nobre rio", e a história de um "grande homem", que deixaria sua "obra" por onde passou. Embora não explicitada, sugere-se uma aproximação, a mais importante, entre o aniversariante e a "imagem viva de uma grande vida". Nessa entrada, como em tantas outras, uma "mistura de gêneros" faria do diário "ao mesmo tempo o observatório da vida e o ponto de encontro" dos escritos de um autor (LEJEUNE, 2014, p. 305): por um lado, trata-se de um diário de viagem formado por uma sequência de entradas - aliás, na de 24 de agosto daquele ano, Nabuco (2006, p. 194) planejou um livro de viagens, O Niágara, jamais escrito -; por outro, o diário abre-se a uma forma propícia ao ensaio, a qual procurava dimensionar a grandeza do senador Nabuco de Araújo, que desde a sua morte demandava do filho uma obra vislumbrada na infinidade de documentos deixados.

\section{OS LIVROS EM BRANCO}

A entrada de 13 de março de 1884 já anunciava os dois grandes livros da maturidade de Nabuco (2006, p. 233) e sua correlação enquanto 
escritas de trajetórias de vida, ao mesmo tempo imbricadas e diversas: "Livros em branco: biográfico, meu Pai. Autobiográfico". Adiados pela intensa atividade política, principalmente a campanha abolicionista, os "livros em branco", que resultariam em Um estadista do Império e Minha formação, vinham sendo preparados de forma fragmentária e lacunar pelas escritas de si, as quais continuaram participantes também na fase de redação, na primeira década republicana. Como demonstraram os vários biógrafos e estudiosos de Nabuco, ele se viu forçado a um ostracismo a partir da proclamação da República, que o estimulou a se dedicar aos seus escritos. No que se refere ao diário e à carta, irmanaram-se tanto para dar vazão à indignação e à angústia vivenciadas por Nabuco, quanto para suscitar a prática do ensaio, requerido pelas obras em gestação. Angela Alonso (2006, p. 203) observa que nesse período se pode acompanhar no diário "sua progressiva reconversão ao tradicionalismo de origem", e, assim, o "elogio da família imperial e dos estadistas do Segundo Reinado desemboca na crítica horrorizada à elite republicana e ao militarismo".

Entre os recursos mobilizados para essa crítica, Nabuco reiterou tanto nos diários e nas cartas, quanto nos ensaios, o tópico da anarquia das repúblicas hispano-americanas, que circulou no Império como estratégia de diferenciação e de superioridade, e que lhe permitia lamentar a similitude dos vícios na igualdade de regime, a exemplo das imagens dramáticas da entrada de 28 de fevereiro de 1891 :

\footnotetext{
[...] "Nós estamos atravessando uma crise", diz-se no Brasil. Engano! Estamos no redemoinho republicano da América. Somos um cadáver girando no sorvedouro da anarquia. [...] Temos, pois, de ficar brasileiros, vendo o Brasil tornar-se uma Venezuela, um México, uma Argentina, um Chile: propriedade do déspota do dia (NABUCO, 2006, pp. 292-293).
}

Contudo, na sequência, sinaliza para uma resistência dele e de um pequeno grupo: "o nosso dever consiste em manter na minoria o nível moral superior ao político, dissociar o desenvolvimento moral da incurável estagnação política (a estagnação na voragem)" (NABUCO, 2006, p. 293). $\mathrm{O}$ resgate da memória do pai e do Império fez com que Nabuco não se estagnasse na voragem republicana, que lhe parecia tragar todo um passado e ele mesmo. Se muito antes vislumbrara a "imagem de uma grande vida” nas pedras do Niágara, agora precisava torná-la perene por meio da historiografia, mergulhando na execução do livro que daria sentido tanto a sua vida, quanto a sua carreira de escritor: "Desde 1893, porém, o assunto que deveria ser a grande devoção literária da minha vida, a Vida de meu 
pai, tinha-se já apossado de mim e devia seguidamente durante seis anos ocupar-me até absorver-me" (NABUCO, 2012, p. 253). Justamente escrito para Minha formação, esse par "minha vida, a Vida de meu pai" - título pelo qual costumava se referir a Um estadista do Império - reverberava a proximidade entre biografia e autobiografia que a entrada de 1884 prometia.

Nabuco seguia o caminho que alguns escritores europeus fizeram de suas cartas e de seus diários para a produção de autobiografias ou memórias, o que percebemos se tomamos Um estadista do Império não apenas pela biografia que se assume como a história do Segundo Reinado, mas também como as memórias de uma época de cujo início de declínio o autor foi testemunha privilegiada. Sendo assim, as cartas e os diários seriam um manancial de informações e formulações fragmentárias muitas delas perdidas pela memória e somente recuperáveis pelo registro escrito - para a reconstrução totalizante de um sujeito e de uma época. No que tange ao exercício epistolar, também aplicável ao diário, Brigette Diaz (2016, p. 91) conclui que

"concebido não tanto como uma busca de si, mas como uma produção de si, no duplo sentido de manifestação e de invenção, é bastante lógico querer considerar os resultados ou os impasses desse trabalho sobre si, por uma apreensão retrospectiva de seu percurso".

E as cartas e os diários não apenas teriam esse caráter de fonte passível de reformulação, mas poderiam ser trazidos para um novo espaço discursivo como a voz do passado que irrompesse com sua suposta naturalidade e autenticidade. Dessa maneira, Nabuco (2012, p. 141) deslocou trechos do diário para os capítulos XIV - "Nova York (1876-77)" - e XV - "O meu diário de 1877" - de Minha formação, pois seriam o seu "modo de sentir naquela época”; e recuperou, nas páginas finais de Um estadista do Império, a "nota íntima" de 1877 dos Diários do pai, o "seu último estado de espírito": "Escusar-me de chefe e ministro. Ser liberal avulso não militante. Político per acidens, para censurar, moderar, historiar, aconselhar. Monarquia” (NABUCO, 1997, p. 1105). Palavras que também convinham ao filho Nabuco para se acomodar aos novos tempos da República.

\section{PENSAMENTOS SOLTOS}

Por mais que Um estadista do Império e Minha formação possibilitassem o reconhecimento de Nabuco como escritor, parecia- 
-lhe que aquela voz dos bastidores, que ecoava do diário e das cartas, era tão legítima quanto essas obras. Ainda que não se atrevesse a publicar os escritos íntimos em vida, encontrou nas máximas uma forma de expressão em consonância com uma prática de escrita fragmentária que lhe era cara há muito tempo. Em seu diário, frente aos mais diversos acontecimentos e estados de espírito, recorria muitas vezes a frases lapidares que podiam ser consideradas como máximas; basta lembrar "O destino de um homem desaparece no do Todo como uma rocha nas espumas da queda" (NABUCO, 2006, p. 188), na entrada do dia 14 de agosto de 1877 , sobre a visita às cataratas do Niágara, citada anteriormente. A identificação de máximas em sua correspondência não é menos comum do que em seu diário, já que, tida "como 'nobre, sábia e útil', a máxima pode facilmente ser inserida numa carta, exemplificando a brevidade, uma das qualidades epistolares fundamentais" (HAROUCHE-BOUZINAC, 2016, p. 153). Além disso, a partir da noção de que o diário e a carta seriam campos privilegiados de experimentação da prosa ensaística, pode-se deduzir o quanto as máximas também foram transpostas para o estilo de outros trabalhos.

As máximas de Nabuco chegaram ao público apenas em seu último livro de 1906, em língua francesa e com o sugestivo título Pensées détachées et souvenirs, embora tenha sido produzido entre 1893 e 1894. A expressão pensées détachées refere-se a três livros de máximas sobre variados assuntos - especialmente religião, arte e literatura -, as quais vão desde uma frase até um pequeno texto próximo das formulações das entradas do diário, o que reforça a impressão de serem ao mesmo tempo partes deslocadas de um todo e partes autônomas sem pretensão de formar um todo. Aliás, alguns trazem as notações típicas do diário, como "Petrópolis, 15 de março" (NABUCO, 1949b, p. 253).

Os souvenirs, por sua vez, constituem uma espécie de apêndice que abriga textos divulgados anteriormente em português: o antológico capítulo de Minha formação, "Massangana", e o texto "L’influence de Renan”, de Escritos e discursos literários (1901). A configuração do volume, portanto, reforça a ligação estreita que as máximas estabelecem com os gêneros híbridos da obra de Nabuco, no caso a autobiografia e o ensaio. Aliás, o Pensées détachées et souvenirs e Escritos e discursos literários um "livro de fragmentos" e uma "obra fragmentária", nos termos de José Veríssimo (1979b, p. 106) - homenageavam no título e na proposta o Feuilles détachées (1892), de Renan, lançado na esteira da autobiografia 
Souvenirs d'enfance et de jeunesse (1883) e em contraponto à historiografia, e constituído por discursos, artigos, cartas, retratos e outros textos esparsos.

Carolina Nabuco revelou que o pai considerava justamente Pensées détachées "o melhor", "a obra preferida”, porque teria sido aquela "em que mais pôs de sua alma, onde mais vive, mais se revela” (NABUCO, 1929, p. 300). E completa essa passagem com a frase que encerra as máximas 155 e 156 do Livro II, nas quais Nabuco defende a prevalência de uma frase decisiva e recorrente, que concentraria o que houvesse de mais íntimo de um autor, em detrimento de toda uma obra:

O tema de um trabalho, quer de história, quer de ficção, é apenas o libreto do escritor, coisa que o público põe de lado, como as palavras de uma ópera, para procurar a frase musical nele encerrada. Há muito autor que não tem senão uma frase que lhe serve, como no teatro de Wagner, de leitmotiv. E como envelhece depressa o resto da obra! Quer em literatura, quer em música, só sobrevive o leitmotiv (NABUCO, 1949b, p. 197).

É vossa impressão pessoal das coisas, o som que a vida vos arrancou do coração, e não vossas pesquisas, nem vossos estudos, que dará vossa verdadeira medida. Não deixeis pois entrar em vossa frase senão o que tenha passado pelo vosso sentimento, e traga algo realmente vosso (NABUCO, 1949b, p. 199).

Antes de Carolina, os primeiros leitores de Pensées detachées reconheceram todo um mundo interior sob a concisão das máximas. Machado (apud ARANHA, 2003, p. 139), em carta de 19 de agosto de 1906, na qual esboçou uma crítica ao livro, assinalou à maneira das máximas que tanto apreciava: "O seu interior está aqui aberto às vistas por aquela forma lapidária que a memória retém melhor”. José Veríssimo (1979a, p. 40) foi certeiro ao intitular o artigo sobre esse livro de "As 'confissões' do Sr. Joaquim Nabuco", pois, se "há um livro que provoque e autorize a crítica a fazer a psicologia do autor, é um livro de pensamentos, que é sempre um livro de confissões intencionais ou inconscientes". Por outro lado, ele percebeu que a ocorrência das máximas não era restrita a Pensées detachées, mas se revelava uma constante nos escritos de Nabuco:

[...] Dentre outras qualidades relevantes distingue-se na sua obra a tendência ao conceito, isto é, ao pensamento em forma de máxima, terminando uma série de considerações ou resumindo a ideia que as dirigiu. [...] Os seus livros abundam em juízos, máximas, pensamentos, geralmente finos, às vezes sutis, alguns raros, todos distintos. [...] (VERÍSSIMO, 1979a, p. 21).

Veríssimo (1976, pp. 104-105), quando da recepção do primeiro volume de Um estadista do Império, em 1898, já observara que o livro 
estava "salpicado" de "conceitos, onde se acha também o imprevisto, a originalidade da ideia”, e citara alguns deles, que podiam ser lidos sem se conhecer a passagem correspondente: "A fatalidade das revoluções é que sem os exaltados não é possível fazê-las e com eles é impossível governar" (NABUCO apud VERÍSSIMO, 1976, pp. 104-105). Nessa direção, Ricardo Salles (2002, pp. 218-219) explicou que essa obra segue "o antigo topos da Historia Magistra Vitae do modelo da historiografia da antiguidade clássica e, mais especificamente, da historiografia política do Renascimento"; e, para tanto, Nabuco valeu-se, entre outros aspectos, da "intercalação ao longo do relato de máximas e aforismos como forma de isolar e enfatizar os conhecimentos adquiridos na história” (p. 218-219). Seja como recurso para o autoconhecimento ou para o ensinamento de condutas morais e políticas, as máximas foram requisitadas pelos diversos escritos de Nabuco.

\section{O ENSAIO EM FRAGMENTOS}

Entre 1893 e 1894, Nabuco simultaneamente reunia tanto os fragmentos de si, que poderiam permanecer inéditos ou ser reunidos em futuros volumes, quanto os fragmentos do pai, para compor um dos "livros em branco", que vislumbrara em 1884. A tarefa consistia na organização de uma imensa quantidade de materiais deixados pelo Senador Nabuco de Araújo - cartas, discursos, recortes de jornal, diário, entre outros -, enfrentando assim uma ameaça de apagamento da memória do Império e de suas grandes figuras atribuídas ao cenário republicano de confrontos e de perseguições. No breve prefácio ao primeiro tomo de Um estadista do Império, de 1897, Nabuco valeu-se da expressão "fragmentos de vida" para se referir a esses papéis que revelavam o próprio pai, em consonância com a experiência de historiadores, memorialistas e autores de autobiografias em relação aos vestígios do passado:

[...] Com a sua biblioteca, esse arquivo absorveu parcela por parcela sua existência, toda de gabinete, de pensamento, de trabalho intelectual incessante. Não podia eu manuseá-los sem sentir nesses papéis a presença do seu espírito, sem compreender que eles eram os fragmentos de sua vida, que ela devia achar-se ali inteira, completa para quem a pudesse reconstruir, e que era preciso que alguém um dia a desprendesse deles (NABUCO, 1997, p. 31).

O caráter fragmentário das fontes condicionou todo o processo de preparação da obra: "Uma vez terminado o trabalho de separação 
ou eliminação, tratei de reunir e dispor cronologicamente o material escolhido, ligando-o peça por peça de modo a formar o arcabouço completo da obra" (NABUCO, 1997, p. 31). Inclusive o "arcabouço completo" dos outros dois volumes já estava pronto, "só lhes restando a forma de livro, que outra mão lhes poderia dar sem prejuízo do fundo" (p. 32). Além da modéstia em relação ao seu talento como escritor, Nabuco parece enfatizar a importância das "peças" para compor um todo, o qual, uma vez armado, seria o suficiente para aquele que se dispusesse a dar a "forma de livro". Essa proeminência das "peças" em Um estadista do Império não passou despercebida por Veríssimo (1976, pp. 106-107), ao apontar que a narrativa seria prejudicada "no seu desenvolvimento e na pureza das suas linhas" pela "intercalação de longos trechos de discursos, relatórios, projetos e até avisos acompanhados das competentes fórmulas de destinação e de cortesia oficial", o que poderia comprometer o estatuto literário da obra. Em carta de 23 de junho de 1898, Nabuco discordou do crítico, justificando que a intercalação dos documentos faria de seu livro uma "história documentada antes de tudo", embora se pudesse "extrair uma edição popular em um só volume, que lhe pareça mais em forma literária”." Como se sabe, tal "edição popular" não foi levada adiante. A intercalação de tantos fragmentos, além da função de resgate e de fundamentação da memória, sugere uma correlação com toda uma prática de escrita de Nabuco, colocando em risco, na perspectiva de Veríssimo, uma "forma literária”, entendida como coesa e unitária.

Em direção oposta, Nabuco planejava se dedicar a uma série de obras fragmentárias, de acordo com a entrada do diário de 8 de março de 1894:

Eu quisera publicar além de Foi volue, que está escrita, um volume de Pensées, espécie de deversoir do Foi volue e mais tarde em português os volumes aproveitando minhas diversas publicações anteriores (resumindo tudo em algumas páginas). Um volume aproveitando correspondências de Londres para o Jornal do Commercio e a Razón. Outro aproveitando colaboração do Paiz. Outro literário aproveitando escritos, discursos, etc., esparsos. Outro aproveitando discursos parlamentares e campanha abolicionista. Outro aproveitando manuscritos, viagens, etc. Outro sobre amigos, aproveitando cartas deles. Outro de viagens (NABUCO, 2006, pp. 352-353).

O Foi volue - Mysterium fidei é um caso exemplar do trânsito e da afinidade das escritas de si e dos gêneros híbridos na trajetória de

${ }^{1}$ Original pertencente ao acervo de José Veríssimo, no Arquivo da Academia Brasileira de Letras. 
Nabuco. Esse livro, escrito em francês, de caráter autobiográfico e sobre a "reversão religiosa", permaneceu inédito até $1971 .^{2} \mathrm{Em}$ seu primeiro capítulo, traz o texto "Massangana: recordações da infância" - publicado no Pensées detachées et souvenirs e Minha formação -, além de diversas máximas do livro de 1906. E, com exceção de Escritos e discursos literários, todos esses textos, como tantos outros, permaneceram nas páginas do diário, restando à posteridade a incumbência de divulgar uma parcela deles. ${ }^{3}$ De todas as formas, destaca-se a intenção de aproveitar a extensa produção jornalística para compor alguns volumes, um "fragmentarismo consagrado" - na feliz expressão cunhada por Alexandre Eulálio (1992, p. 50) para se referir à "forma obrigatória de colaboração para a imprensa" que o ensaísmo assumiu no contexto brasileiro do século XIX.

Enquanto os ensaios de Nabuco continuavam entregues à fragmentação das colunas e à efemeridade dos jornais, ele era um leitor atento daqueles autores que conseguiam reunir os seus em coletâneas, como atestam os exemplares que lhe pertenceram, Essais de critique et d'histoire, de Taine (5 $5^{\text {a }}$ edição de 1887), e Ensaios e estudos de filosofia e crítica, de Tobias Barreto (1875), ambos com muitas marcas de leituras. ${ }^{4} \mathrm{O}$ livro de Tobias motivou inclusive uma parte considerável dos comentários de "A reação alemã e George Sand", em 5 de setembro de 1875, no folhetim "Aos domingos" que Nabuco mantinha no jornal O Globo. Apesar de considerar Barreto um "moço cheio de talento e de audácia", fez reparos à forma, vazada em um "dialeto profundamente pedantesco, uma linguagem livremente original", "grande desprezo do estilo e mesmo prevenção contra a frase, que para ele é a roupa de domingos" (NABUCO, 1875, [s.p.]). Tal diagnóstico não impediu que Nabuco, em seu exemplar, marcasse várias frases e passagens que por algum motivo lhe chamaram a atenção. O gesto do leitor que desprende fragmentos do livro se irmana aos pensamentos soltos tão constantes em seus escritos. Logo no primeiro

\footnotetext{
2 Texto estabelecido por Claude-Henri e Nicole Frèches, e editado pelo Departamento de Estudos Portugueses da Universidade de Provença, França. A tradução em português, por Aída Batista, teve duas edições, em 1984 e 2013, ambas pela Editora Massangana da Fundação Joaquim Nabuco.

3 Carolina de Nabuco reuniu textos esparsos em alguns volumes das Obras completas, em 1949 (Discursos parlamentares e Campanhas de imprensa), e, mais recentemente, em 2013, José Murilo de Carvalho, Cícero Sandroni e Leslie Bethell publicaram dois alentados volumes sob o título Joaquim Nabuco: correspondente internacional (1882-1891), pela editora Global.

${ }^{4}$ Os volumes integram o acervo da Fundação Joaquim Nabuco, em Recife.
} 
ensaio do livro, "A ciência da alma, ainda e sempre contestada", Nabuco deixou um traço à margem da seguinte passagem:

O senso íntimo, em si mesmo, é semelhante a um belo céu do sol posto, olhado de repente: veem-se apenas umas quatro estrelas. Porém o número aumenta, à proporção que se encara, e após instantes, fulguram aos milhões. Tal é o espetáculo dos fatos subjetivos que a memória traz à tona do lago interior (BARRETO, 1875, pp. 5-6).

Entre os defeitos da forma, a comparação poética para um assunto tão abstrato talvez tivesse calado fundo em um leitor que se depararia com o "lago interior" da memória.

\section{O ENSAIO DA AUTOBIOGRAFIA}

Mesmo um livro mais íntimo como Minha formação não escapou ao "fragmentarismo consagrado" a que o ensaio e a produção intelectual em geral estavam atrelados no Brasil. Entre abril e julho de 1896, muitos dos seus capítulos saíram no jornal Comércio de São Paulo, sob o título $A$ minha formação monárquica, que explicitava os propósitos mais políticos que pessoais dessa autobiografia. A publicação foi retomada na prestigiosa Revista Brasileira, dirigida por José Veríssimo, na qual Nabuco também divulgou alguns capítulos de seu outro "livro em branco", Um estadista do Império. A consagração efetiva só viria com a edição em volume pela Garnier, em 1900. No entanto, diante do recebimento dos dois primeiros exemplares, que "esperava com certa ansiedade" (NABUCO, 2006, p. 433), ele confessou sentimentos contraditórios na entrada do diário de 30 de junho daquele ano:

[...] Impressão geral da obra agradável; de alguns capítulos, "Massangana", "Tautphoeus", "Meu pai”, talvez melhor do que nas provas. No todo, porém, a sensação de vazio, de insuficiência, de decepção, de enfado, que estou certo, mesmo a obra mais genial, tivesse eu escrito as mais belas páginas de Chateaubriand ou de Renan, me havia de causar, pelo que agradeci a Deus fervorosamente, contente, refugiando-me nele (NABUCO, 2006, p. 433).

Além da sintonia com a faceta religiosa de muitas das máximas de Pensées detachées e de páginas de Foi volue, essa entrada pode ser considerada uma reveladora contraposição entre a insatisfação de Nabuco diante do "todo" da obra realizada e a sua preferência por algumas partes dela, ou ainda, por alguns fragmentos. Trata-se de três capítulos, que 
seriam os mais pessoais em relação a três momentos decisivos da vida de um homem que pouco se revelava, mesmo na privacidade das cartas e dos diários: o espaço paradigmático da infância (capítulo XX), o primeiro grande mestre ("O barão de Tautphoeus", capítulo XXV) e aquele que lhe moldou a vida adulta (capítulo XVIII). Não causa estranheza, portanto, que Nabuco tenha compartilhado com Carlos Magalhães de Azevedo, em carta de 26 de novembro de 1900, que Minha formação não era seu "livro íntimo": "Deste só há nela os capítulos Massangana e Tautphoeus"; talvez tenha omitido aí "Meu pai" pela obviedade.

Por outro lado, "Massangana" foi o capítulo que mais se desprendeu de Minha formação, por vontade tanto de Nabuco, quanto daqueles que logo o elegeram como peça antológica. Fazendo jus ao caráter inaugural do livro como autobiográfico, "Massangana" foi o primeiro texto a ser escrito, em 1893, para ocupar o primeiro capítulo do inédito Foi volue. Contudo, em Minha formação, o autor deslocou-o para quase o final do volume. Consciente de haver transgredido as expectativas do gênero, Nabuco (2012, p. 187) adicionou a "Massangana" uma longa nota de rodapé:

\begin{abstract}
A razão que me fez não começar pelos anos de infância foi que estas páginas tiveram, ao serem primeiro publicadas, feição política que foram gradualmente perdendo, porque já ao escrevê-las diminuía para mim o interesse, a sedução política. A primeira ideia fora contar a minha formação monárquica; depois, alargando o assunto, minha formação político-literária ou literário-política; por último, desenvolvendo-se sempre, minha formação humana, de modo que o livro confinasse com outro, que eu havia escrito antes sobre minha reversão religiosa. É deste livro, de caráter mais íntimo, composto em francês há sete anos, que traduzo este capítulo para explicar a referência feita às minhas primeiras relações com os escravos.
\end{abstract}

Essa passagem da "formação política" à "formação humana", experimentada na elaboração da autobiografia, foi anunciada no capítulo que antecede "Massangana", o XIX, "Eleição de deputado", no qual ele discorre sobre sua vida pública dedicada à causa abolicionista a partir de 1879. Nabuco (2012, p. 180) confessa que "trazia da infância e da adolescência o interesse, a compaixão, o sentimento pelo escravo - bolbo que devia dar a única flor da minha carreira...", retomando essa intromissão do passado nas frases finais do capítulo: "Esse episódio não será talvez descabido nestas recordações” (p. 185). O descabimento poderia consistir em abrir espaço à intimidade em um livro que até aquele momento tinha

\footnotetext{
${ }^{5}$ Original da carta pertencente ao acervo da Fundação Joaquim Nabuco, em Recife.
} 
estado aberto apenas ao mundo da política e das letras. Em lugar dos riscos de uma nova versão, ele preferiu traduzir para o português o capítulo escrito anos antes para outro livro, "de caráter mais íntimo". "Massangana” assume, dessa maneira, o hibridismo característico das escritas de si, que o tornam um texto adaptável a várias destinações, tanto à vertente política de Minha formação, quanto à vertente humana de Foi volue.

Alexandre Eulalio (1992, p. 64) deu um lugar de destaque a Minha formação no que ele chama de "ensaio rememorativo", o qual, no caso brasileiro, foi praticado de maneira fragmentária e ocasional: "o mais intrinsecamente ensaístico de todo o nosso memorialismo, no sentido de ser análise compreensiva e intelectualizada de uma vida cheia de plenitude". Enquanto para Eulalio (p. 62) essa modalidade combinaria "o narrativo, o descritivo e o interpretativo", para Philippe Lejeune (2014, p. 17, grifos do autor), embora a autobiografia deva ser "principalmente uma narrativa", isso não excluiria "a importância do discurso na narração autobiográfica”:

“Trata-se de uma questão de proporção ou, antes, de hierarquia: estabelecem-se naturalmente transições com os outros gêneros da literatura íntima (memórias, diário, ensaio) e uma certa latitude é dada ao classificador no exame de casos particulares (LEJEUNE, 2014, p. 17)."

A narrativa no livro de Nabuco é mais um pretexto do que um fio condutor, podendo ser invertida ou interrompida como em "Massangana", em que a descrição do engenho da "mãe-madrinha", Ana Rosa Falcão de Carvalho, e o ensaio em torno da escravidão predominam. Por outro lado, a experiência fundamental da infância, que decidiu o "emprego ulterior" da vida de Nabuco (2012, p. 190), é contada em poucas linhas:

[...] Eu estava uma tarde sentado no patamar da escada exterior da casa, quando vejo precipitar-se para mim um jovem negro desconhecido, de cerca de dezoito anos, o qual se abraça aos meus pés suplicando-me pelo amor de Deus que o fizesse comprar por minha madrinha para me servir. Ele vinha das vizinhanças, procurando mudar de senhor, porque o dele, dizia-me, o castigava, e ele tinha fugido com risco de vida... Foi este o traço inesperado que me descobriu a natureza da instituição com a qual eu vivera até então familiarmente, sem suspeitar a dor que ela ocultava.

Nos parágrafos seguintes, Nabuco (2012, p. 191) esboça uma controversa "saudade do escravo", retida em sua recordação "como um jugo suave, orgulho exterior do senhor, mas também orgulho íntimo do escravo, alguma coisa parecida com a dedicação do animal que nunca 
se altera, porque o fermento da desigualdade não pode penetrar nela”. Passagens distantes da virulência daquele que teria sido seu livro de estreia, A escravidão, de 1870 , deixado incompleto e inédito, e o livro que já nasceu clássico, $O$ abolicionismo, de 1883, ambos compostos na melhor tradição do ensaio histórico e panfletário do Brasil do século XIX. Contudo, em trecho intitulado "O cemitério", de A escravidão, enveredou pela própria experiência para denunciar como até mesmo a disposição dos mortos revelava a desigualdade dos vivos:

Vi desses cemitérios ao lado do cemitério dos brancos. Nada atestava que ali, nesse barro, entre pedras amontoadas e as urzes, houvesse um lugar de último descanso... os animais passavam livremente sobre esse chão. Nada! Nem uma inscrição, nem uma lápide, nem uma cruz de pau tosco dizia que ali havia poeira humana. Num desses engenhos ou fazendas íamos caminhando, quando o proprietário nos disse que aí enterrava seus escravos. Foi preciso que nos advertisse... para sabermos que pisávamos terra sagrada por lágrimas sem preço (NABUCO, 2010, pp. 38-39).

"Desses engenhos ou fazendas" da juventude ao "Massangana" da maturidade, a entrada nos cemitérios de escravos teve seu apelo de revelação amplificado. Ao final do capítulo de Minha formação, Nabuco recordou sua visita doze anos após ter deixado o engenho em que fora criado, por volta da época da escrita de $A$ escravidão. Dessa vez, ele não precisava do alerta do fazendeiro, pois sabia onde estava pisando. Da capelinha que abrigava os restos mortais de Dona Ana Rosa, ele ingressou "no cercado onde eram enterrados os escravos". Diante da paisagem transformada pela presença da usina e do trabalho livre, Nabuco voltouse aos escravos desaparecidos:

O sacrifício dos pobres negros, que haviam incorporado as suas vidas ao futuro daquela propriedade, não existia mais talvez na minha lembrança... Debaixo dos meus pés estava tudo o que restava deles, defronte dos columbaria onde dormiam na estreita capela aqueles que eles haviam amado e livremente servido. Sozinho ali, invoquei todas as minhas reminiscências, chamei-os a muitos pelos nomes, aspirei no ar carregado de aromas agrestes, que entretém a vegetação sobre as covas, o sopro que lhes dilatava o coração e lhes inspirava a sua alegria perpétua (NABUCO, 2012, p. 195).

Para o escritor, pouco afeito à narração, não importava deter-se nos nomes e em suas histórias, mas preparar o momento solene que marcaria uma das decisões mais importantes de sua vida, ponto de partida de Foi volue e ápice de Minha formação. O pequeno trecho escrito em 1870 fora esquecido no livro inacabado, mas continuava o potencial da imagem de 
que se pisava em "terra sagrada por lágrimas sem preço”. A frase final de "Massangana” redimensiona aquele sentimento de veneração, dessa vez tomado como clamor de justiça em nome dos "Santos pretos" que, mesmo na condição de escravos, foram devotamente fiéis e não se revoltaram contra seus senhores:

[...] Eram essas ideias que me vinham entre aqueles túmulos, para mim, todos eles, sagrados, e então ali mesmo, aos vinte anos, formei a resolução de votar a minha vida, se assim fosse dado, ao serviço da raça generosa entre todas que a desigualdade da sua condição enternecia em vez de azedar e que por sua doçura no sofrimento emprestava até mesmo à opressão de que era vítima um reflexo de bondade... (NABUCO, 2012, p. 196).

"Massangana" justificava tanto uma trajetória política, devotada à causa mais urgente do século XIX no Brasil, quanto uma trajetória literária, a qual, embora fracassada no verso, era ovacionada na prosa, ao mesmo tempo irretocável no estilo e maleável na tipologia, ora relato das origens, ora ensaio sobre a escravidão. Desde cedo, o entrelaçamento entre as escritas de si e o ensaio orientaram a produção de Nabuco, seja para erigir grandes painéis de uma época, como em Um estadista do Império e Minha formação, seja para se fragmentar em frases e textos esparsos que poderiam migrar entre vários suportes e obras. Mas qualquer que fosse a direção que tomasse, Nabuco sempre pretendia dar a conhecer a si próprio e ao país.

\section{REFERÊNCIAS}

ALONSO, Angela. Nabuco na intimidade. Novos estudos - CEBRAP, n. 74, 2006, pp. 201205 .

ARANHA, Graça (org.). Machado de Assis E Joaquim Nabuco. Correspondência. $3^{\underline{a}}$ ed. Rio de Janeiro: Topbooks, 2003.

BARRETO, Tobias. Ensaios e estudos de filosofia e crítica. Recife: Tipografia Mercantil, 1875 .

DIAZ, Brigitte. O gênero epistolar ou o pensamento nômade: formas e funções da correspondência em alguns percursos no século XIX. Trad. Brigitte Hervot e Sandra Ferreira. São Paulo: Edusp, 2016.

EULALIO, Alexandre. O ensaio literário no Brasil. In: WALDMAN, Berta \& DANTAS, Luiz (orgs.). Escritos. São Paulo / Campinas: Editora da Unesp / Editora da Unicamp, 1992, pp. 11-74. 
HAROCHE-BOUZINAC, Geneviève. Escritas epistolares. Trad. Ligia Fonseca Ferrera. São Paulo: Edusp, 2016.

LEJEUNE, Philippe. O pacto autobiográfico: de Rousseau à Internet. Trad. Jovita Maria Gerheim Noronha e Maria Inês Coimbra Guedes. $2^{\underline{a}}$ ed. Belo Horizonte: Editora UFMG, 2014 .

NABUCO, Carolina. A vida de Joaquim Nabuco. $2^{\underline{a}}$ ed. São Paulo: Companhia Editora Nacional, 1929.

NABUCO, Joaquim. A reação alemã e George Sand. O Globo, Rio de Janeiro, 5 de setembro de 1875 .

NABUCO, Joaquim. Cartas a amigos. V. 1. Carolina Nabuco (org.). São Paulo: Instituto Progresso Editorial, 1949a.

NABUCO, Joaquim. Pensamentos soltos. Camões e assuntos americanos. São Paulo: Instituto Progresso Editorial, 1949b.

NABUCO, Joaquim. Um estadista do Império. 2 v. 5 $5^{\underline{a}}$ ed. Rio de Janeiro: Topbooks, 1997.

NABUCO, Joaquim. Diários. Evaldo Cabral de Mello (org.). Rio de Janeiro: Bem-Te-Vi, 2006.

NABUCO, Joaquim. A escravidão. Rio de Janeiro: Batel / Fundação Biblioteca Nacional, 2010.

NABUCO, Joaquim. Minha formação. São Paulo: Editora 34, 2012.

NABUCO, Joaquim. Minha fé. $2^{\underline{a}}$ ed. Trad. Aida Batista do Val. Recife: Fundação Joaquim Nabuco / Editora Massangana, 2013.

SALLES, Ricardo. Joaquim Nabuco: um pensador do Império. Rio de Janeiro: Topbooks, 2002.

VERÍSSIMO, José. Um historiador político. In: Estudos de literatura brasileira, $1^{\underline{a}}$ série. Belo Horizonte / São Paulo: Ed. Itatiaia / Edusp, 1976, pp. 99-114.

VERÍSSIMO, José. As "Confissões" do Sr. Joaquim Nabuco. In: Últimos estudos de literatura brasileira: $7^{\text {a }}$ série. Belo Horizonte / São Paulo: Ed. Itatiaia / Edusp, 1979a, pp. 21-42.

VERÍSSIMO, José. A obra literária de Joaquim Nabuco. In: Últimos estudos de literatura brasileira: $7^{\underline{a}}$ série. Belo Horizonte / São Paulo: Ed. Itatiaia / Edusp, 1979b, pp. 97-109. 